\title{
$\beta$-Aminobutyric Acid Primes an NADPH Oxidase-Dependent Reactive Oxygen Species Production During Grapevine-Triggered Immunity
}

\author{
Carole Dubreuil-Maurizi, Sophie Trouvelot, Patrick Frettinger, Alain Pugin, David Wendehenne, and \\ Benoît Poinssot
}

Université de Bourgogne, INRA 1088, and CNRS 5184, Unité Mixte de Recherche Plante-Microbe-Environnement, 17 Rue Sully, F-21000 Dijon, France

Submitted 8 January 2010. Accepted 19 April 2010.

\begin{abstract}
The molecular mechanisms underlying the process of priming are poorly understood. In the present study, we investigated the early signaling events triggered by $\boldsymbol{\beta}$-aminobutyric acid (BABA), a well-known priming-mediated plant resistance inducer. Our results indicate that, in contrast to oligogalacturonides (OG), BABA does not elicit typical defense-related early signaling events nor defensegene expression in grapevine. However, in OG-elicited cells pretreated with BABA, production of reactive oxygen species (ROS) and expression of the respiratory-burst oxidase homolog $R b o h D$ gene were primed. In response to the causal agent of downy mildew Plasmopara viticola, a stronger ROS production was specifically observed in BABA-treated leaves. This process was correlated with an increased resistance. The NADPH oxidase inhibitor diphenylene iodonium (DPI) abolished this primed ROS production and reduced the BABA-induced resistance (BABA-IR). These results suggest that priming of an NADPH oxidase-dependent ROS production contributes to BABA-IR in the Vitis-Plasmopara pathosystem.
\end{abstract}

Besides constitutive barriers including the cell wall and cuticle, plants develop inducible defense responses to cope with infection by pathogens. The induced defense mechanisms following plant perception of pathogen-derived elicitors are generally sufficient to trigger plant resistance. General elicitors, also referred to as pathogen-associated molecular patterns (PAMPs) in innate immunity, are essential components of the pathogen lifestyle and include, for instance, flagellin, lipopolysaccharides, the elongation factor EF-Tu, or products released by plant or pathogen cell wall-degrading enzymes (Nurnberger et al. 2004). These last endogenous elicitors are considered as damage-associated molecular patterns (Boller and Felix 2009). All these compounds are perceived by pattern-recognition receptors, as described in animals (Zipfel and Felix 2005). The

Corresponding author: B. Poinssot: E-mail: benoit.poinssot@dijon.inra.fr; Telephone: +33-380-693-458; Fax: +33-380-693-226.

* The $\boldsymbol{e}$-Xtra logo stands for "electronic extra" and indicates that three supplemental figures are published online. Also, Figures 1, 2, and 3 appear in color online.

This article is in the public domain and not copyrightable. It may be freely reprinted with customary crediting of the source. The American Phytopathological Society, 2010. binding of elicitors to their corresponding receptors triggers cell signaling cascades, which have been extensively studied in the past ten years (Garcia-Brugger et al. 2006; Gomez-Gomez and Boller 2002). In grapevine for example, oligogalacturonides (OG) released from the degradation of the plant cell wall were shown to induce changes in free cytosolic calcium concentration $\left(\left[\mathrm{Ca}^{2+}\right]_{\text {cyt }}\right)$, activation of mitogen-activated protein kinases (MAPK), and production of reactive oxygen species (ROS) (Poinssot et al. 2003). These events precede the expression of defense-related genes encoding pathogenesis-related (PR) proteins and enzymes involved in the production of antimicrobial compounds such as phytoalexins (Hammerschmidt 1999; van Loon et al. 2006). ROS are involved in cell-wall strengthening and, at least in several pathosystems, contribute to the development of a localized cell death called hypersensitive response (HR) (Torres et al. 2006). In Arabidopsis thaliana, it has been shown that AtRboh mutants impaired in the NADPH oxidase-dependent ROS production displayed reduced HR in response to Pseudomonas syringae (Torres et al. 2002). Finally, all these biochemical and physiological changes prevent pathogen growth at the infection site.

Upon exposure to certain pathogenic or nonpathogenic organisms, plants show an enhanced capacity to mobilize defense responses against further attack by a broad spectrum of pathogens. This process, also referred to as the priming phenomenon, is correlated with one or both a faster or stronger activation of defense responses and leads to enhanced resistance (Conrath et al. 2006). Contrary to PAMP-triggered immunity and systemic acquired resistance (SAR) which usually confer resistance through the direct elicitation of defense mechanisms, priming phenomenon shows increased defense responses only upon pathogen attack (van Hulten et al. 2006). Thus, wellknown biological phenomena such as mutually beneficial interactions and induced systemic resistance need priming for their establishment. For instance, interaction of plants with mycorrhizal fungi or rhizobacteria was shown to enhance their capacity to overcome biotic stresses by priming their defense responses (Pozo et al. 2002; van Loon et al. 1998).

The nonprotein amino acid $\beta$-aminobutyric acid (BABA), a compound rarely found in nature, has been known for years as a resistance inducer protecting a broad range of plant species from pathogens or cold, drought, and salt stresses (Cohen et al. 1999; Jakab et al. 2001, 2005). However, elicitation and priming depend on both the molecule concentration applied and the plant species (Jakab et al. 2001). For example, in A. thaliana, a high concentration of BABA directly induces the salicylic acid (SA)-signaling marker $P R-1$ gene 
expression, whereas a low concentration primes this expression in BABA-induced resistance (BABA-IR) (van Hulten et al. 2006). However, in grapevine, BABA-IR only uses the priming phenomenon against Plasmopara viticola, even at high BABA concentrations (Hamiduzzaman et al. 2005). Moreover, the signaling pathway that controls the BABA-IR depends on the pathogen species. In A. thaliana, BABA-IR against Pseudomonas syringae and Botrytis cinerea depends on SA, whereas abscissic acid is required for the resistance to Plectosphaerella cucumerina and Alternaria brassicicola through the formation of callose-rich papillae (Ton and Mauch-Mani 2004; Zimmerli et al. 2000, 2001). Moreover, in the case of oomycetes such as Hyaloperonospora arabidopsidis and $P$. viticola, the BABA-IR coincides with a primed deposition of callose at the infection site in A. thaliana and grapevine, respectively (Hamiduzzaman et al. 2005; Zimmerli et al. 2000). Previously, it has been shown that the BABA-IR is mostly based on the priming of defense responses rather than on the direct activation of these responses. For instance, a low BABA concentration does not directly induce but primes the expression of $P R-1$ and jamonic acid (JA)-marker $L O X$ (lipoxygenase) genes after infection in A. thaliana and in grapevine, respectively (Hamiduzzaman et al. 2005; Ton et al. 2005; Zimmerli et al. 2000, 2001).

Even though many studies provide insights in the understanding of BABA-IR, the molecular mechanisms of priming remain unknown. In the present study, we show that BABA must not be considered as a typical elicitor in grapevine cells, as it does not induce early defense-related signaling events and defense-gene expression, in contrast to OG. However, we provide first evidence that it primes a $R b o h D$ gene expression that could be responsible for the elicited $R b o h D$-dependent ROS production in grapevine cells. This priming of ROS production was also observed in BABA-treated leaves and correlated with resistance to $P$. viticola. In planta moreover, the NADPH oxidase-inhibitor diphenylene iodonium (DPI) abolished this primed ROS production and reduced the BABA-IR to $P$. viticola.

\section{RESULTS}

BABA does not elicit any variation of $\left[\mathrm{Ca}^{2+}\right]_{\text {cyt }}$, nitric oxide production, ROS production, MAPK phosphorylation, or defense-related gene expression in grapevine cells.

Elicitors have been widely reported to induce signaling events involved in triggering defense responses. In tobacco cell suspensions for example, cryptogein, a protein secreted by Phytophthora cryptogea, triggers ion fluxes, activation of protein kinases such as MAPK, ROS and nitric oxide (NO) production, and defense-related gene expression within the first hours (Garcia-Brugger et al. 2006). The same events were shown to occur in grapevine cell suspensions elicited by OG (Poinssot et al. 2003). Elicitation by cryptogein in tobacco leaves induces resistance to Phytophthora parasitica, the causal agent of black shank disease (Ricci et al. 1989). In the case of OG, the induction of defense-related gene expression leads to resistance against $B$. cinerea in grapevine and $A$. thaliana (Aziz et al. 2004, 2007; Ferrari et al. 2007; Galletti et al. 2008).

As BABA triggers protection against a broad range of plant pathogens, we first checked whether BABA itself was able to trigger early defense responses and defense-related gene expression in grapevine cell suspensions. Therefore, we tested the ability of BABA to mediate changes in $\left[\mathrm{Ca}^{2+}\right]_{\text {cyt }}$, NO and ROS production, MAPK phosphorylation, and defense-related gene expression (Fig. 1). Elicitor-induced responses were checked by using OG. BABA was used at $500 \mu \mathrm{M}$, because this concentration efficiently induced resistance in grapevine plants against $P$. viticola (Hamiduzzaman et al. 2005). At this concentration, no significant cell death was observed on grapevine cell suspensions until $24 \mathrm{~h}$ after treatment (Supplementary Fig. 1A).

Variations of $\left[\mathrm{Ca}^{2+}\right]_{\mathrm{cyt}}$ after BABA or OG treatment were monitored using grapevine cells expressing the $\mathrm{Ca}^{2+}$ reporter apoaequorin addressed to the cytosol (Vandelle et al. 2006). In control cells, the basal $\left[\mathrm{Ca}^{2+}\right]_{\text {cyt }}$ was about $0.2 \mu \mathrm{M}$ (Fig. 1A). OG elicited a transient variation of $\left[\mathrm{Ca}^{2+}\right]_{\text {cyt }}$. The $\left[\mathrm{Ca}^{2+}\right]_{\text {cyt }}$ began to increase at $1 \mathrm{~min}$, peaked at $0.38 \mu \mathrm{M}$ at $3 \mathrm{~min}$ and returned to the background level after $20 \mathrm{~min}$. In BABAtreated cells, the $\left[\mathrm{Ca}^{2+}\right]_{\mathrm{cyt}}$ was similar to the level monitored in control cells. Therefore, contrary to OG, BABA did not induce any variation of $\left[\mathrm{Ca}^{2+}\right]_{\mathrm{cyt}}$ in grapevine cells.

Intracellular NO production in grapevine cells was measured by fluorescence, using the NO-specific probe 4,5-diaminofluorescein diacetate (DAF-2DA) (Vandelle et al. 2006). Fluorescence increased quasi-linearly in control cells within 3 $\mathrm{h}$, probably due to a constitutive NO production, as previously shown in tobacco cell suspensions (Fig. 1B) (Besson-Bard et al. 2008). OG induced a fast increase in fluorescence, indicative of an induced NO production. The fluorescence reached a plateau after 45 min of treatment. In contrast, BABA did not trigger any increase in fluorescence, indicating that it did not elicit intracellular NO production.

MAPK phosphorylation was assessed by immunoblotting on protein extracts from OG- or BABA-treated cells with polyclonal antibodies raised against the active phosphorylated form of human ERK1/2 (extracellular signal-regulated kinases 1 and 2 ). These antibodies specifically react with the activated form of plant ERK-related MAPK (Lebrun-Garcia et al. 1998). In the samples corresponding to OG-treated cells, two phosphorylated MAPK orthologs with molecular masses of 45 and $49 \mathrm{kDa}$ were detected (Fig. 1C). Their respective phosphorylation peaked at $15 \mathrm{~min}$ and returned almost to the basal level within $60 \mathrm{~min}$. Of importance, immunoblotting performed using antibodies raised against the human total ERK1/2 MAPK showed that OG did not change the amount of the two MAPK orthologs during the experiment. This observation indicates that the signals immunodetected with the antibodies raised against the active MAPK are related to an increase in phosphorylation of the two MAPK rather than an increase in the amount of the corresponding proteins. In BABA-treated cells, BABA did not modify the global amount of MAPK and did not induce their phosphorylation (Fig. 1C).

$\mathrm{H}_{2} \mathrm{O}_{2}$ production was determined using chemiluminescence of luminol. A basal $\mathrm{H}_{2} \mathrm{O}_{2}$ production was observed in control cells (Fig. 1D). The addition of $\mathrm{OG}$ on grapevine cells led to $\mathrm{H}_{2} \mathrm{O}_{2}$ production that reached $12 \mathrm{nmol}$ of $\mathrm{H}_{2} \mathrm{O}_{2}$ per gram of FWC (fresh weight of cells) at $20 \mathrm{~min}$ and decreased slowly within the next $70 \mathrm{~min}$. On the contrary, BABA did not trigger any production of $\mathrm{H}_{2} \mathrm{O}_{2}$ in grapevine cells.

The expression of five genes that are known to be involved in plant defense was analyzed by real-time quantitative polymerase chain reaction (RT-qPCR). RbohD is predicted to encode an NADPH oxidase potentially involved in ROS production. Phenylalanine ammonia lyase (PAL) and stilbene synthase (STS) are two key enzymes involved in the biosynthesis of grapevine phytoalexins. $L O X$ is a marker gene for the JAsignaling pathway, and $P R-2$ encodes a $\beta-1,3$ glucanase produced during pathogen infection. None of these genes was upregulated during the $8 \mathrm{~h}$ of BABA treatment (only the 4-h data are shown), whereas the transcript of all these five genes accumulated roughly $4 \mathrm{~h}$ after $\mathrm{OG}$ treatment (Fig. 1E). Thus, BABA did not elicit the expression of these defense genes. 
BABA does not prime any variation of $\left[\mathrm{Ca}^{2+}\right]_{\text {cyt }}$, NO production, or MAPK phosphorylation in OG-elicited cells.

Since BABA itself did not elicit any of the early signaling events or any studied defense-gene expression, we investigated whether BABA could prime these events in plant cells challenged by biotic stress, thus conferring an enhanced defense response on plants. To test this hypothesis, we pretreated grapevine cells with $500 \mu \mathrm{M}$ BABA (or water) during the $24 \mathrm{~h}$ before elicitation with OG. The same defense-related events were studied (Fig. 2).
A 24-h water pretreatment did not modify the OG-dependent responses (data not shown). OG induced a similar kinetic of $\left[\mathrm{Ca}^{2+}\right]_{\mathrm{cyt}}$ variations in both water and BABA pretreated grapevine cells (Fig. 2A). The $\left[\mathrm{Ca}^{2+}\right]_{\text {cyt }}$ peaked at $3 \mathrm{~min}$ and returned to the control level within the next minutes. These data indicate that BABA pretreatment did not inhibit nor potentiate the OG-induced changes in $\left[\mathrm{Ca}^{2+}\right]_{\text {cyt }}$. Similarly, BABA pretreatment did not affect the production of NO triggered by OG, since the production of NO was similar in water- and BABA-pretreated cells (Fig. 2B). Concerning gene expression, we confirmed that STS and $P A L$ genes are up-regulated in
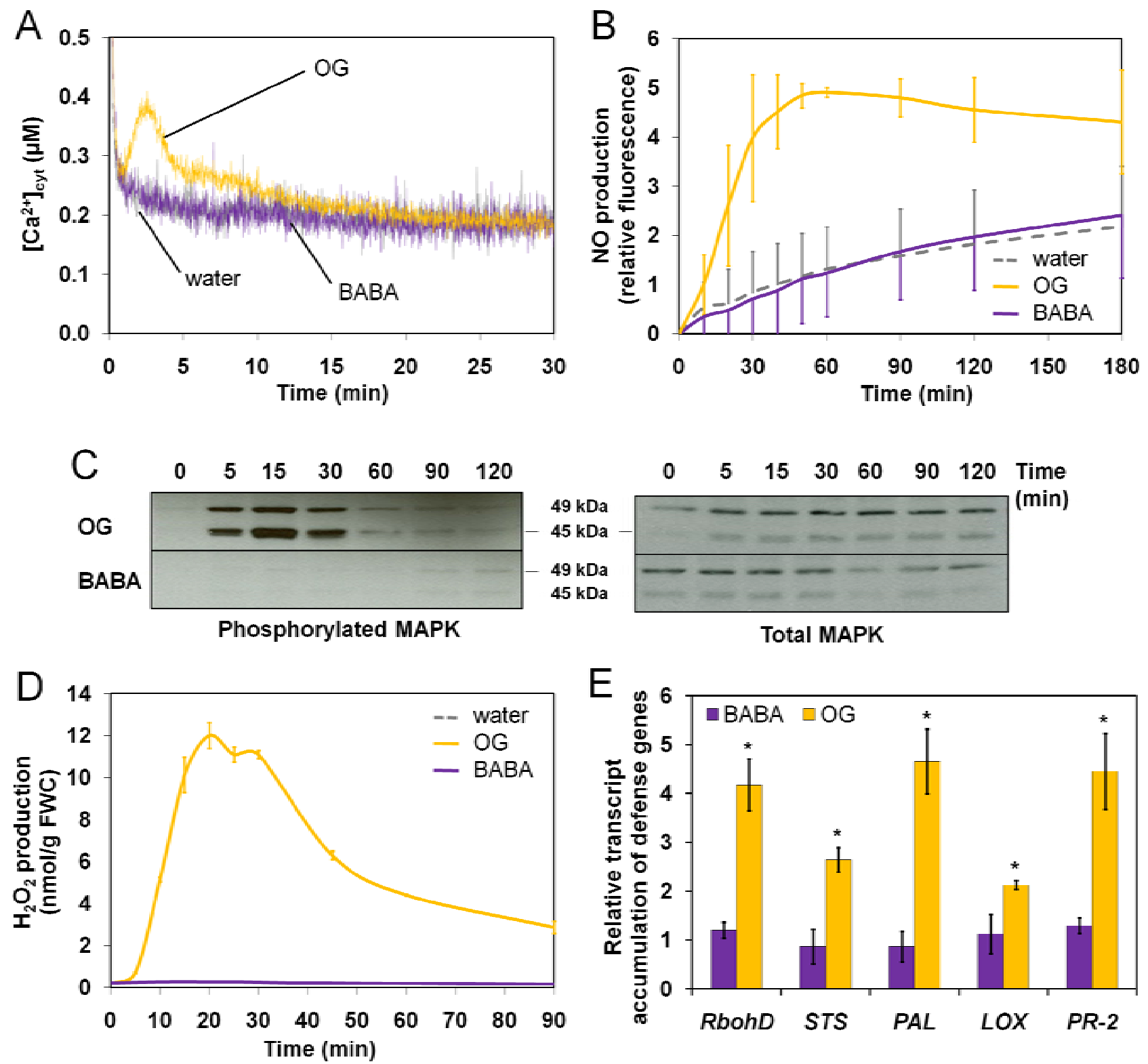

Fig 1. Effect of $\beta$-aminobutyric acid (BABA) on early signaling events and defense gene expression in grapevine cells. Cells were treated with water, oligogalacturonides $(\mathrm{OG})$ at $0.5 \mathrm{~g} /$ liter, or $500 \mu \mathrm{M}$ BABA. A, Variations of free cytosolic calcium concentration $\left(\left[\mathrm{Ca}^{2+}\right]_{\text {cyt }}\right)$ in apoaequorin-transformed grapevine cells. Results are representative of three independent experiments. B, Intracellular nitric oxide (NO) production monitored using 4,5-diaminofluorescein diacetate. Values are means \pm standard error (SE) of three independent experiments. C, Regulation of mitogen-activated protein kinase (MAPK) phosphorylation. Phosphorylated and total MAPK from protein extracts were analyzed by Western blotting, using an antibody raised against human phosphorylated (activated) ERK1/2 (extracellular signal-regulated kinases 1 and 2) and an antibody raised against human total ERK1/2, respectively. Results are representative of three independent experiments. $\mathbf{D}, \mathrm{H}_{2} \mathrm{O}_{2}$ production measured using chemiluminescence of luminol. Values are means \pm SE of triplicate assays of a representative experiment out of three independent ones. E, Expression of defense genes at $4 \mathrm{~h}$ after treatment. The transcript accumulation of genes encoding NADPH oxidase (RbohD), stilbene synthase (STS), phenylalanine ammonia lyase (PAL), lipoxygenase $(L O X)$, and $\beta$-1,3-glucanase $(P R-2)$ was analyzed by real-time quantitative polymerase chain reaction. After normalization with $E F 1 \alpha$, results are expressed as the fold changes in transcript level compared with the control (water-treated) and are the mean \pm SE of technical duplicates from three biological replicates $(n=6)$. Asterisks indicate statistically significant difference between BABA and OG treatments using Student's $t$-test for pairwise comparison $(P<$ $0.05)$. 
response to OG (Fig. 1E), but no significant difference in their transcript accumulation was observed in water- or BABApretreated cells (Supplementary Fig. 2). Regarding MAPK phosphorylation, immunoblots revealed that BABA pretreatment did not affect the dynamic of OG-induced MAPK phosphorylation (Fig. 2C). Furthermore, in both water- and BABApretreated cells, the amount of MAPK did not evolve during OG treatment. These results showed that these early signaling events are not primed by BABA treatment in OG-elicited grapevine cells.
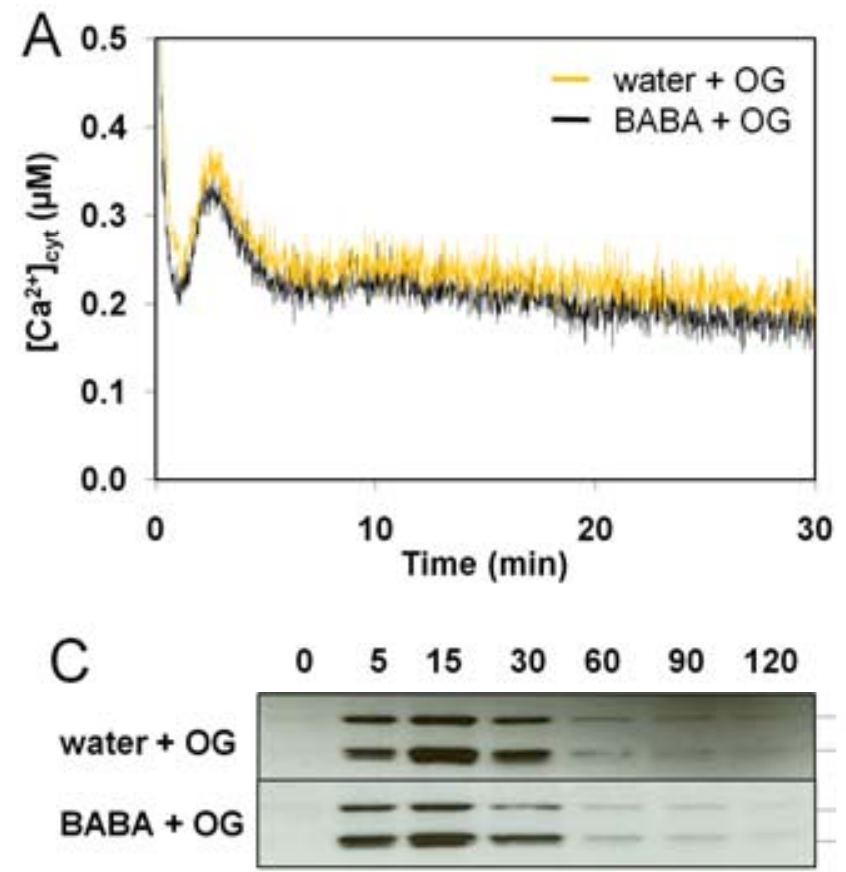

Phosphorylated MAPK
BABA primes both ROS production and

RbohD transcript accumulation in OG-elicited cells.

Contrary to the variation of $\left[\mathrm{Ca}^{2+}\right]_{\mathrm{cyt}}$, NO production, and MAPK phosphorylation, we observed that $\mathrm{H}_{2} \mathrm{O}_{2}$ production was targeted by BABA priming. Indeed, in both water- and BABA-pretreated cells, OG induced a transient production of $\mathrm{H}_{2} \mathrm{O}_{2}$, the maximum being observed at 20 min (Fig. 3A). However, $\mathrm{H}_{2} \mathrm{O}_{2}$ production was twofold higher in BABA-pretreated cells. Although this production decreased after $20 \mathrm{~min}$ in both experiments, it remained higher in BABA-pretreated cells until
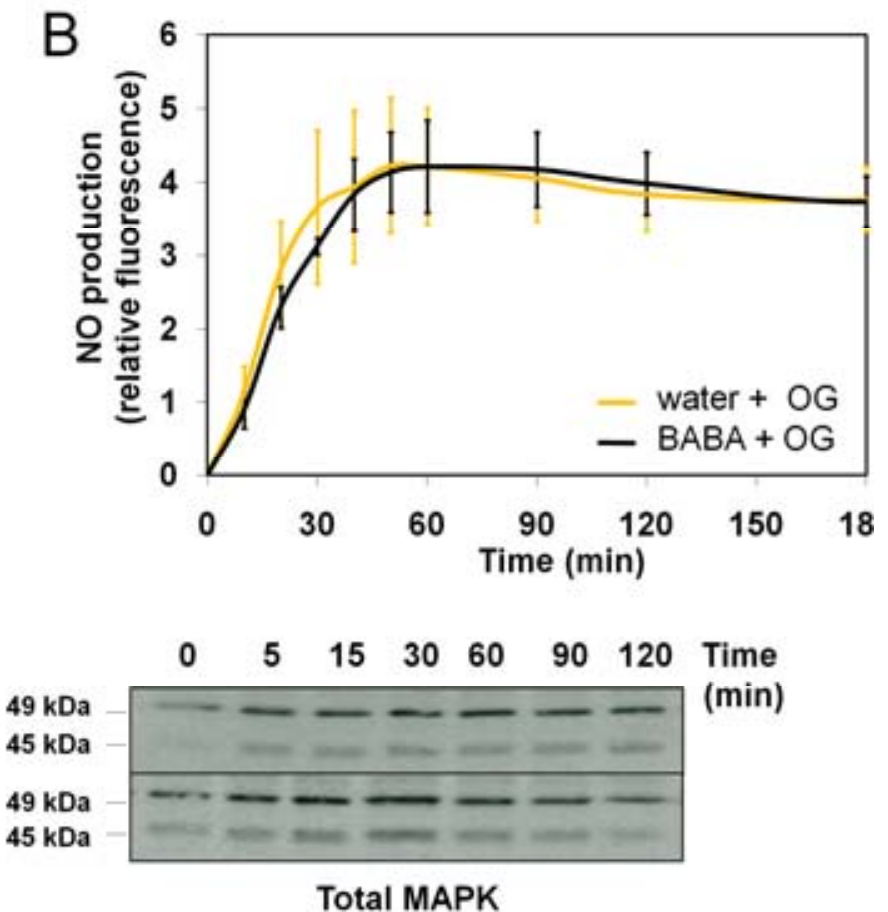

Fig. 2. Effect of $\beta$-aminobutyric acid (BABA) pretreatment on oligogalacturonide (OG)-induced early signaling events in grapevine cells. Cells were treated with water or $500 \mu \mathrm{M}$ BABA $24 \mathrm{~h}$ prior to elicitation with $\mathrm{OG}$ at $0.5 \mathrm{~g} /$ liter. A, Variations of free cytosolic calcium concentration $\left(\left[\mathrm{Ca}{ }^{2+}\right]_{\mathrm{cyt}}\right)$ in apoaequorintransformed grapevine cells. Results are representative of three independent experiments. B, Intracellular nitric oxide (NO) production monitored with 4,5diaminofluorescein diacetate. Values are means \pm standard error of three independent experiments. C, Regulation of mitogen-activated protein kinase (MAPK) phosphorylation. Phosphorylated and total MAPK from protein extracts were analyzed by Western blotting using an antibody raised against human phosphorylated (activated) ERK1/2 (extracellular signal-regulated kinases 1 and 2) and an antibody raised against human total ERK1/2, respectively. Results are representative of three independent experiments.
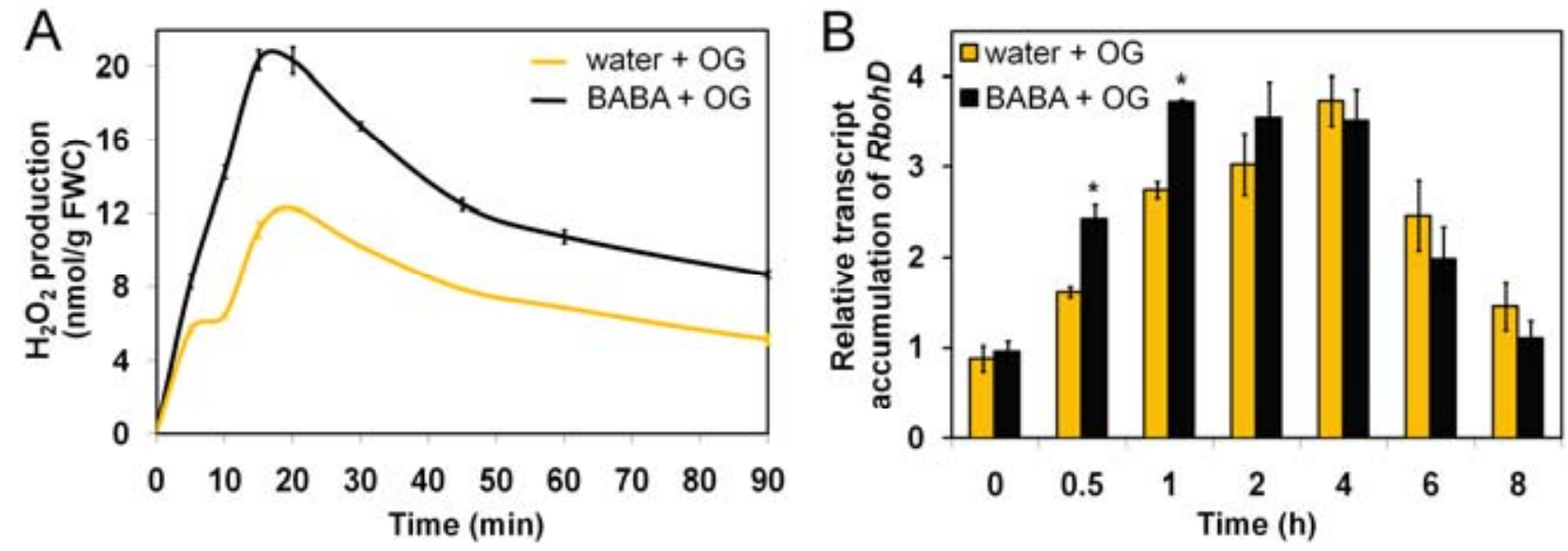

Fig. 3. Priming of oligogalacturonides (OG)-induced $\mathrm{H}_{2} \mathrm{O}_{2}$ production and $R b o h D$ expression in $\beta$-aminobutyric acid (BABA) pretreated grapevine cells. Cells were treated with water or $500 \mu \mathrm{M}$ BABA $24 \mathrm{~h}$ prior to elicitation with $\mathrm{OG}$ at $0.5 \mathrm{~g} /$ liter. $\mathbf{A}, \mathrm{H}_{2} \mathrm{O}_{2}$ production was measured using chemiluminescence of luminol. Values are means \pm standard error (SE) of triplicate assays of one representative experiment out of three. B, Expression of RbohD gene. The transcript accumulation was analyzed by real-time quantitative polymerase chain reaction. After normalization with $E F 1 \alpha$, results are expressed as the fold change in transcript level compared with the control (water + water-treated) and are the mean \pm SE of technical duplicates from three biological replicates $(n=6)$. Asterisks indicate statistically significant difference between BABA + OG and water + OG treatments, using Student's $t$-test for pairwise comparison $(P<0.05)$. 
the end of experiment. The results showed that BABA pretreatment of cells strongly primed $\mathrm{H}_{2} \mathrm{O}_{2}$ production during $\mathrm{OG}$ elicitation.

Rboh genes encode plasma membrane NADPH oxidases that are responsible for ROS production during plant defense responses (Simon-Plas et al. 2002; Torres et al. 2002, 2006). Therefore, we studied the effect of BABA pretreatment on the expression of the grapevine $R b o h D$ gene after elicitation with OG (Fig. 3B). In water-pretreated cells, OG induced a transcript accumulation of $R b o h D$ gene after $30 \mathrm{~min}$, with a maximum after $4 \mathrm{~h}$ of treatment. In BABA-pretreated cells, RbohD transcript accumulation was significantly higher than in waterpretreated cells at $30 \mathrm{~min}$ and $1 \mathrm{~h}$, the maximum being observed after $1 \mathrm{~h}$ of treatment. This result shows that BABA primed the accumulation of $R b o h D$ transcripts during $\mathrm{OG}$ elicitation.

\section{BABA-primed ROS production is correlated with the BABA-IR against $P$. viticola in grapevine leaves.}

Since BABA primed $R b o h D$ gene expression in OG-treated grapevine cells, we analyzed its regulation in planta. For this purpose, detached leaves were sprayed with water or BABA and then were inoculated $24 \mathrm{~h}$ after with the oomycete $P$. viticola. Results indicated that RbohD transcript accumulation was not significantly primed in BABA-treated leaves at $0,1,2$, 3 , and 4 days postinoculation (dpi) (data not shown). Thereafter, we investigated whether BABA might, nevertheless, promote the priming of $\mathrm{H}_{2} \mathrm{O}_{2}$ production in plants challenged by the pathogen. At 3 dpi, leaf disks were analyzed for $\mathrm{H}_{2} \mathrm{O}_{2}$ production using 3,3'-diaminobenzidine (DAB) staining (ThordalChristensen et al. 1997), and spreading of the pathogen was revealed by fluorescence observations using aniline blue staining (Hamiduzzaman et al. 2005). The BABA-IR was observed at $7 \mathrm{dpi}$ by measuring the sporulation index of $P$. viticola (Trouvelot et al. 2008).

To transpose the BABA effect on $\mathrm{H}_{2} \mathrm{O}_{2}$ production in grapevine tissues, we first checked that $\mathrm{BABA}$ does not act as an elicitor in plant leaves. No brown precipitate, revealing the production of $\mathrm{H}_{2} \mathrm{O}_{2}$, was detected at 3 days after BABA treatment in uninoculated leaves (data not shown). From 3 days after inoculation with $P$. viticola, no DAB staining was detectable in water-treated leaves, whereas a strong $\mathrm{H}_{2} \mathrm{O}_{2}$ production appeared in BABA-treated leaves (Fig. 4A). This strong ROS production in BABA-treated leaves was observed mostly in mesophyll tissue (Fig. 4B). Moreover, aniline blue staining revealed that, in BABA-treated leaves, pathogen growth was clearly altered in the $\mathrm{H}_{2} \mathrm{O}_{2}$-producing zones such as stomata or parenchyma cells but was normal in zones without DAB staining (Fig. 4B). These host cells in contact with the pathogen were altered, evoking the HR-like cell death. These observations suggest the participation of ROS in pathogen alteration.

BABA-IR was confirmed with a clear reduction of $P$. viticola sporulation. As expected, at $7 \mathrm{dpi}$, the pathogen sporulates normally in water-treated leaves, whereas its sporulation was totally abolished in BABA-treated leaves (Fig. 4B). These results suggest that BABA-IR to $P$. viticola is associated with the primed $\mathrm{H}_{2} \mathrm{O}_{2}$ production.

To demonstrate that the primed $\mathrm{H}_{2} \mathrm{O}_{2}$ production is NADPH oxidase-dependent, $24 \mathrm{~h}$ before BABA treatment, we treated leaves with DPI, which, at low concentrations, specifically inhibits this class of enzymes in plants (Pugin et al. 1997). DPI alone slightly enhanced disease triggered by $P$. viticola, showing an involvement of NADPH oxidase in basal resistance of plants (Fig. 4B). But DPI suppressed the $\mathrm{H}_{2} \mathrm{O}_{2}$-related brown precipitates and mycelium alterations observed in BABA-treated leaves. Pathogen sporulation was higher in BABA-treated leaves pretreated with DPI compared with BABA-treated leaves (Fig.
4B). All these results indicated that the NADPH oxidase-dependent primed ROS production participates in BABA-IR to $P$. viticola in grapevine but seems to be independent of $R b o h D$ transcript accumulation.

\section{DISCUSSION}

BABA has been reported for years to induce resistance against biotic and abiotic stresses in plants (Cohen et al. 1999; Jakab et al. 2001, 2005). However, the molecular mechanisms underlying BABA-IR remain largely unknown. In parallel, it has been shown that most of the molecules able to trigger plant resistance possess elicitor activities that induce cellular signaling events leading to the expression of defense responses, including a defense transcriptome activation (Asai et al. 2002; Aziz et al. 2007; Ferrari et al. 2007; Galletti et al. 2008; Zipfel et al. 2004). Thus, based on these findings, we hypothesized that the BABA-IR could be related to the activation of early signaling events by BABA itself. Therefore, we investigated in grapevine cells the effect of BABA on variations of $\left[\mathrm{Ca}^{2+}\right]_{\text {cyt }}$, $\mathrm{NO}$ and ROS production, MAPK phosphorylation, and defense gene expression compared with the elicitor OG.

BABA was used at $500 \mu \mathrm{M}$, because this concentration efficiently induced resistance in grapevine against $P$. viticola (Hamiduzzaman et al. 2005), even if a lower concentration was used in other pathosystems (Cohen et al. 1999; Reuveni et al. 2001; Ton and Mauch-Mani 2004; Ton et al. 2005; Zimmerli et al. 2001, 2008). Our results showed that, at $500 \mu \mathrm{M}$, BABA induced neither variation of $\left[\mathrm{Ca}^{2+}\right]_{\mathrm{cyt}}$, nor production of $\mathrm{NO}$ and ROS, nor phosphorylation of the two MAPK (Fig. 1). By contrast to the priming inducer benzothiadiazole (BTH) used in A. thaliana (Beckers et al. 2009), BABA treatment did not affect the global total amount of the two MAPK detected in grapevine. Thus, the priming effect on MAPK accumulation differs between BABA and a low concentration of BTH, suggesting different molecular mechanisms. Besides the distinct structures of the molecules, this difference might also be due to the plant species or the concentration used. Moreover, in our system, the same results have been obtained on ROS production with $0.05,0.5,5$, or $50 \mathrm{mM}$ of BABA. Furthermore, a cell viability assay showed that BABA had no toxic effect on grapevine cells at such concentrations. So, in grapevine, BABA did not possess any ROS-eliciting or toxic activity even at high concentrations. Moreover, analysis by RT-qPCR showed that BABA did not up-regulate the phytoalexin biosynthesisrelated genes STS and $P A L$ as well as the JA-marker gene $L O X$ (Fig. 1). To complete these results, RbohD and $P R-2$ genes were not induced by BABA. Conversely, the expression of these defense-related genes was induced by the elicitor $\mathrm{OG}$, with a maximum at around $4 \mathrm{~h}$ after treatment.

Together with the previous demonstration that BABA was unable to induce the expression of the grapevine defense genes $P R-1, P R-4$, and LOX (Hamiduzzaman et al. 2005), these results indicate that BABA by itself does not elicit early signaling events or the expression of the studied grapevine defense genes. However, at a close concentration, BABA induced a direct activation of $P R-1$ gene expression in A. thaliana (van Hulten et al. 2006). Thus, these data show that BABA-IR requires different mechanisms according to the plant species, as previously mentioned (Jakab et al. 2001).

We next investigated whether the BABA-IR could involve the priming of early signaling events that might be involved in the resistant state of plants. Pretreatment with BABA for $24 \mathrm{~h}$ primed neither variations of $\left[\mathrm{Ca}^{2+}\right]_{\mathrm{cyt}}$, production of $\mathrm{NO}$, nor MAPK phosphorylation in response to $\mathrm{OG}$ in grapevine cells (Fig. 2). It has been previously shown that the NO scavenger cPTIO greatly reduced the $B$. cinerea endoPG1-dependent 
A

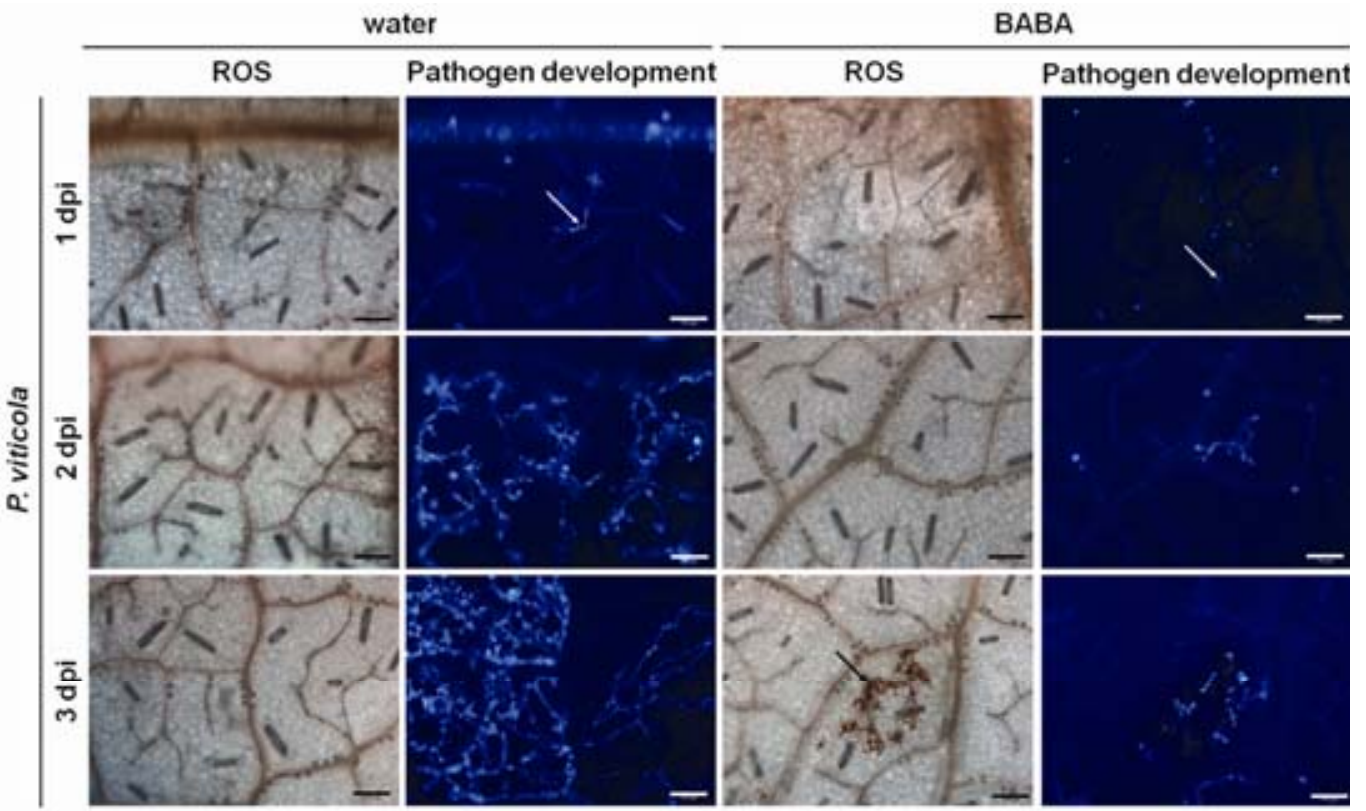

B
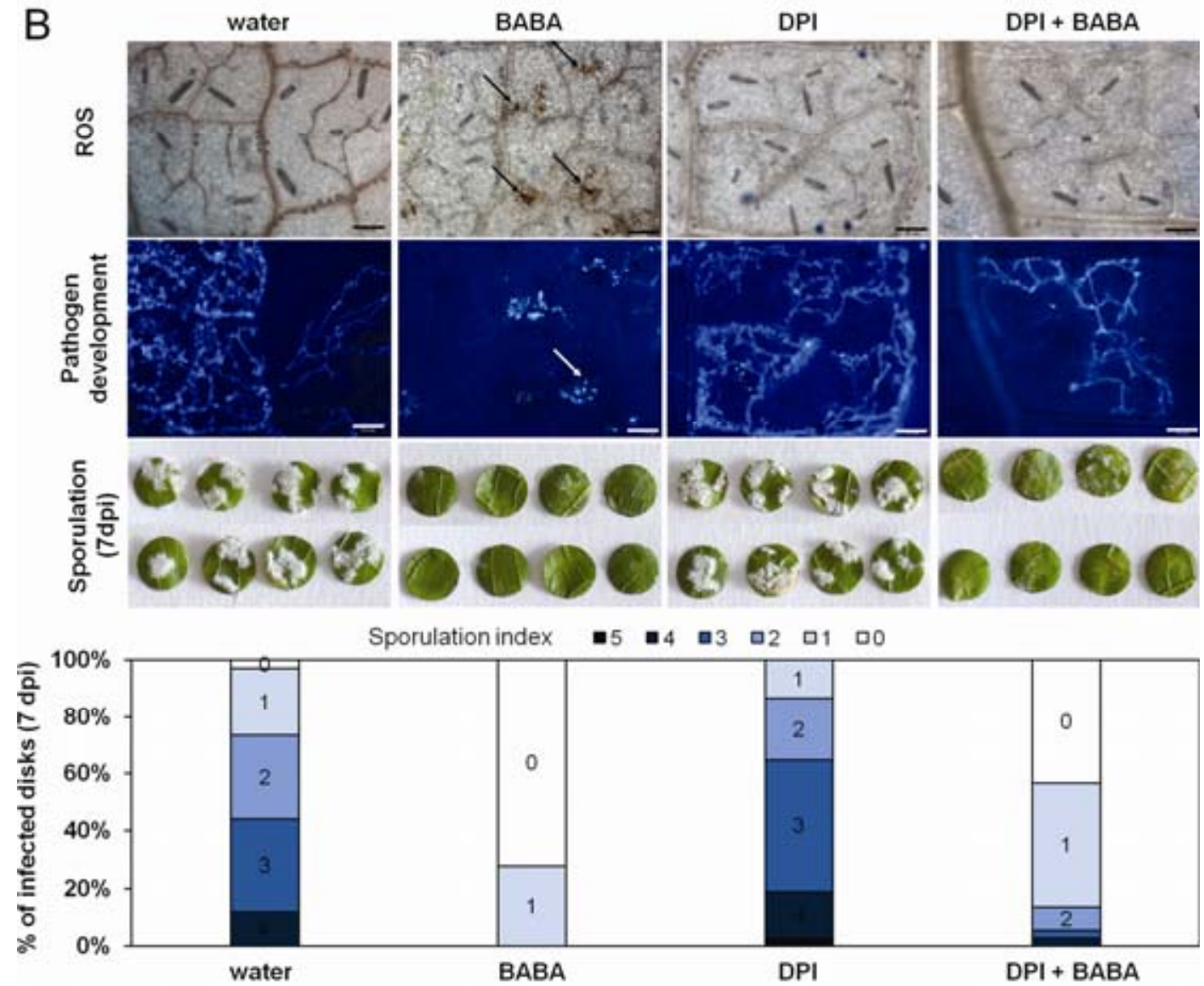

Fig. 4. Priming of $\mathrm{H}_{2} \mathrm{O}_{2}$ production and induced resistance in $\beta$-aminobutyric acid (BABA)-treated leaves inoculated with Plasmopara viticola. Grapevine leaves were treated by spraying with water or $30 \mathrm{mM} \mathrm{BABA} 24 \mathrm{~h}$ prior to challenge inoculation with $P$. viticola sporangia $\left(10^{4} \mathrm{sporangia} / \mathrm{ml}\right)$. $\mathrm{H}_{2} \mathrm{O}_{2}$ production was observed by 3,3'-diaminobenzidine staining, and pathogen colonization in the same leaf tissues was monitored by UV epifluorescence after aniline blue staining at different times after inoculation. Bar $=100 \mu \mathrm{m}$. A, Kinetic of $\mathrm{H}_{2} \mathrm{O}_{2}$ production and pathogen development in BABA-treated leaves inoculated with $P$. viticola. Pathogen infection starts with the encystement of zoospores (white arrow) observed at 1 day postinoculation (dpi) in stomata. Hyphae structures from encysted zoospore develop with haustoria in mesophyll tissue ( $2 \mathrm{dpi})$ and spread in intercellular spaces ( 3 dpi) until sporulation, which appears at 7 dpi with the formation of sporangiophores through stomata. $\mathrm{No}_{2} \mathrm{O}_{2}$ accumulation was observed during the pathogen development in water-treated leaves, whereas in BABA-treated tissues, brown precipitates appeared at 3 dpi, revealing an accumulation of $\mathrm{H}_{2} \mathrm{O}_{2}$ in mesophyll cells (black arrow). B, Effect of NADPH oxidase inhibitor diphenylene iodonium (DPI) on primed $\mathrm{H}_{2} \mathrm{O}_{2}$ production at 3 dpi and induced resistance in BABA-treated leaves inoculated by $P$. viticola. Leaves were treated with water or $5 \mu \mathrm{M}$ DPI by petiole absorption $48 \mathrm{~h}$ prior to inoculation. The index of sporulation of $P$. viticola on leaf disks at 7 dpi was based on a scale between 0 to 5 , which represented the percentage of disk area covered by sporulation $(0=$ no visible sporulation, $1=1$ to $10 \%, 2=$ 10 to $25 \%, 3=25$ to $50 \%, 4=50$ to $75 \%$, and $5=75$ to $100 \%$ ). Values are means of index sporulation ( 35 disks) from two independent experiments. 
transcript accumulation of $P A L$ and STS genes in grapevine cells (Vandelle et al. 2006). In the same way, we showed here that BABA did not prime NO production or the expression of $P A L$ and $S T S$ genes (Fig. 2).

However, under the same conditions, a stronger OG-induced production of $\mathrm{H}_{2} \mathrm{O}_{2}$ was observed, highlighting a role for BABA in priming the elicitor-triggered oxidative burst. In many pathosystems, the oxidative burst was shown to be catalyzed by plasma membrane NADPH oxidases encoded by Rboh genes, particularly RbohD (Sagi and Fluhr 2006). In grapevine cell suspensions elicited by $\mathrm{OG}$, we demonstrated that the accumulation of RbohD transcripts was significantly faster and greater in BABA pretreated cells, compared with the control cells.

Interestingly, this primed $\mathrm{H}_{2} \mathrm{O}_{2}$ production was confirmed in grapevine tissues. Indeed, grapevine leaves treated with BABA showed a stronger $\mathrm{H}_{2} \mathrm{O}_{2}$ production in zones inoculated with $P$. viticola at 3 dpi (Fig. 4). The use of the NADPH oxidase inhibitor DPI confirmed that ROS production primed by BABA depends on NADPH oxidase activity, which likewise plays a role in basal resistance against $P$. viticola. Contrary to cell suspensions, the expression of $R b o h D$ was not primed in planta (data not shown), suggesting that RbohD transcript accumulation might not be solely responsible for ROS production in grapevine leaves. Interestingly, the same results were observed in the tobacco-cryptogein model, in which ROS production depends on NtRbohD in cell suspensions but the cryptogeintriggered HR and SAR were not blocked in NtRbohD-silenced plants (Lherminier et al. 2009). Taken together, these results suggest that, in planta, ROS production depends on an NADPH oxidase encoded by another Rboh gene (seven Rboh genes found in the grapevine genome and 10 in the Arabidopsis one [Sagi and Fluhr 2006]) or by another ROS source, such as a polyamine oxidase (Lherminier et al. 2009) or a peroxidase, even if most of those identified are not inhibited by DPI (Bindschedler et al. 2006; Choi et al. 2007).

The occurrence of oxidative burst preferentially in resistant plants has been repeatedly described (Torres et al. 2006). For instance, in $A$. thaliana, vitamin $\mathrm{B} 1$-induced priming was shown to be dependent on $\mathrm{H}_{2} \mathrm{O}_{2}$ (Ahn et al. 2007). In our experiments, we observed that $\mathrm{H}_{2} \mathrm{O}_{2}$-producing zones were not any more colonized by the oomycete and, rather, showed pathogen alterations (Fig. 4A and B). These results suggested a putative direct toxic effect of ROS as the one triggered during the $\beta-1,3$ glucan sulfate-IR or in tolerant cv. Solaris plants against the same pathogen strain (Trouvelot et al. 2008). Besides displaying toxic effects, ROS could also contribute to signaling events leading to defense reactions able to block sporulation of the pathogen. Among those, callose deposition has been described in many resistant plant-pathogen interactions. In grapevine, pharmacological experiments based on the use of the callose synthase inhibitor 2-deoxy-D-glucose showed that the resistance induced by BABA or $\beta-1,3$ glucan sulfate against $P$. viticola partly depends on callose deposition (Hamiduzzaman et al. 2005; Trouvelot et al. 2008). In A. thaliana, the involvement of callose deposition is observed in resistance induced by BABA or vitamin B1 against $H$. arabidopsidis and Pseudomonas syringae (Ahn et al. 2007; Zimmerli et al. 2000). Accordingly, the callose-deficient mutant pmr4-1 was completely blocked in expressing BABA-IR against Plectosphaerella cucumerina (Ton and Mauch-Mani 2004). Of interest, although the OG-triggered immunity against $B$. cinerea in $A$. thaliana appeared to be independent of ROS and callose formation, Galletti and associates (2008) showed that callose accumulation following OG treatment requires a functional AtRbohD. Together with the cell death colocalized with ROS producing zones in BABA-treated leaves (Fig. 4), we hypothesized that the priming of Rboh-dependent $\mathrm{H}_{2} \mathrm{O}_{2}$ production induced by $\mathrm{BABA}$ might promote $\mathrm{HR}$ and callose deposition, as demonstrated for the $\beta-1,3$ glucan sulfate-IR in grapevine against $P$. viticola (Trouvelot et al. 2008).

Besides $\mathrm{H}_{2} \mathrm{O}_{2}$ production and callose deposition, BABA-IR also requires the priming of defense-gene expression. Studies revealed that BABA treatment in A. thaliana and grapevine infected with $B$. cinerea, Pseudomonas syringae, and $P$. viticola primed the expression of genes involved in defense pathways, such as $P R-1, P R-4$, and $L O X$ (Hamiduzzaman et al. 2005; Ton et al. 2005, Zimmerli et al. 2000, 2001). Here, we showed that BABA also primed the expression of a $R b o h D$ gene encoding an NADPH oxidase in elicited cell suspensions. Similarly, the expression of a JA-signaling $L O X$ gene and the $P R-2$ defense gene encoding a $\beta-1,3$ glucanase, probably involved in the degradation of the pathogen cell wall, were primed by BABA pretreatment in OG-treated grapevine cells (data not shown). However, this priming of defense genes is not a general mechanism, because the expression of genes encoding the phytoalexin biosynthetic enzymes STS and PAL were not modified by BABA.

Finally, the priming phenomenon probably involves unknown signals that remain to be discovered. The recent release of the grapevine genome sequence with the availability of wide genome microarrays should now permit the identification of key genes modulated by BABA in grapevine (Jaillon et al. 2007; Velasco et al. 2007).

Economically, the priming of defense reactions is an optimal strategy for the plant protection against diseases. Primed plants show a yield higher than the elicited ones without pathogen infection (van Hulten et al. 2006). Interestingly, the benefits of priming also outweigh the costs under stress conditions. From an ecologic point of view, the protection of plants by the priming phenomenon should become a future strategy to limit the use of phytochemicals.

\section{MATERIALS AND METHODS}

\section{Grapevine cells.}

Cell culture conditions. Vitis vinifera cv. Gamay was used for cell suspension assays. Wild-type and apoaequorin-transformed cell suspensions were cultivated under continuous light as previously described (Vandelle et al. 2006). Cells were maintained in the exponential phase and were used for treatment one day after subculturing.

Cell treatment. Cells were collected during the exponential growth phase, were washed with M10 buffer $(10 \mathrm{mM}$ morpholineethanesulfonic acid, $175 \mathrm{mM}$ mannitol, $0.5 \mathrm{mM}$ $\mathrm{K}_{2} \mathrm{SO}_{4}, 0.5 \mathrm{mM} \mathrm{CaCl}_{2}$, pH 5.5), and were resuspended at $0.1 \mathrm{~g}$ of fresh weight of cells (FWC) per milliliter. After $2 \mathrm{~h}$ of equilibration $\left(125 \mathrm{rpm}\right.$ at $\left.24^{\circ} \mathrm{C}\right)$, cells were treated with water, OG at $0.5 \mathrm{~g} /$ liter (degree of polymerization between 9 and 20) (Goëmar Laboratories, Saint-Malo, France), or $500 \mu \mathrm{M}$ BABA (Sigma-Aldrich, St. Louis) before measurement of early signaling events. For $\left[\mathrm{Ca}^{2+}\right]_{\text {cyt }}$ variation analysis, 8-day-old transformed cells were collected and washed with M10 buffer. In vivo reconstitution of aequorin was performed by adding $3 \mu \mathrm{M}$ coelenterazine to cell suspensions for $3 \mathrm{~h}$ in the dark.

For priming assays, cells were aseptically treated with water or $500 \mu \mathrm{M}$ BABA in the culture medium for $24 \mathrm{~h}$. Cells were washed three times with M10 buffer, were resuspended at $0.1 \mathrm{~g}$ of FWC per milliliter, and were then equilibrated for $2 \mathrm{~h}$ before treatment with $\mathrm{OG}$ at $0.5 \mathrm{~g} / \mathrm{liter}$.

$\left[\mathrm{Ca}^{2+}\right]_{\text {cyt }}$ variation analysis. $\left[\mathrm{Ca}^{2+}\right]_{\text {cyt }}$ levels were analyzed by measuring luminescence of reconstituted aequorin. The bioluminescence of $250-\mu \mathrm{l}$ aliquots of cells was recorded continuously at 1-s intervals using a luminometer (Lumat LB9507; Berthold Technologies, Wildbad, Germany). The bioluminescence counts were recorded as relative light units per second. 
At the end of the experiment, residual functional aequorin was quantified by adding $300 \mu \mathrm{l}$ of lysis buffer $\left(10 \mathrm{mM} \mathrm{CaCl}_{2} ; 2 \%\right.$ Nonidet $\mathrm{P} 40$, vol/vol; $10 \%$ ethanol, vol/vol), and the resulting increase in luminescence was monitored. The luminescence data were transformed into $\mathrm{Ca}^{2+}$ concentrations as previously described (Aziz et al. 2007).

$\mathrm{H}_{2} \mathrm{O}_{2}$ production measurement $\mathrm{H}_{2} \mathrm{O}_{2}$ production was determined using chemiluminescence of luminol as previously described (Kunz et al. 2006).

Nitric oxide measurement. Intracellular NO accumulation was determined using the specific fluorophore DAF-2DA (Sigma-Aldrich) as described by Vandelle and associates (2006). Briefly, cells were incubated after filtration with 20 $\mu \mathrm{M}$ DAF-2DA for $1 \mathrm{~h}$ in the dark $\left(125 \mathrm{rpm}\right.$ at $\left.24^{\circ} \mathrm{C}\right)$ and were washed three times with fresh M10 buffer to wash off excessive fluorophore. Cells were transferred into 24-well plates (Costar; Corning Inc., Corning, NY, U.S.A.) containing $1 \mathrm{ml}$ of cells per well. NO production was measured using a fluorimeter (Fluoroskan ascent fluorometer; Labsystems, Espoo, Finland) with $\lambda \mathrm{ex}=485 \mathrm{~nm}$ and $\lambda \mathrm{em}=510 \mathrm{~nm}$ filters . Fluorescence was expressed as relative fluorescence units.

Protein and Western blot analyses. Proteins and Western blot analyses were performed as previously described (Vandelle et al. 2006). Briefly, aliquots of cells (2 ml) were harvested by filtration on GF/A filters, were frozen in liquid nitrogen, and were ground in a mortar before protein extraction. Aliquots containing $15 \mu \mathrm{g}$ of proteins were then submitted to $12 \%$ sodium dodecyl sulfate-polyacrylamide gel electrophoresis before transfer to nitrocellulose membrane (Hybond ECL; Amersham Biosciences, Piscataway, NJ, U.S.A.) for Western blot analysis. Detection of total MAPK was performed with an antibody raised against human inactive ERK1/2 (Cell Signaling Technology, Beverly, MA, U.S.A.). Phosphorylated MAPK were detected with an antibody raised against a synthetic phospho-Thr202/Tyr204 peptide corresponding to residues around Thr202/Tyr204 of human phosphorylated ERK1/2 (Cell Signaling Technology). Probing and detection were performed as described in the ECL Western detection kit (Cell Signaling Technology) with a horseradish peroxidase-coupled secondary antibody.

$R N A$ extraction and RT-qPCR analyses. Aliquots $(1 \mathrm{ml})$ of treated cells were harvested by filtration on GF/A filters, were frozen in liquid nitrogen, and were ground in a mortar. Total RNA isolation was obtained with a total RNA isolation kit (Promega, Madison, WI, U.S.A.). Total RNA (1 $\mu \mathrm{g})$ were reverse-transcribed using Superscript III reverse transcriptase kit (Invitrogen, Carlsbad, CA, U.S.A.). The amplification of cDNA ( $8 \mu \mathrm{l}$ of 80 -fold diluted) was performed in a $20-\mu 1$ volume with ABsolute qPCR SYBR green ROX mix (containing Taq polymerase, dNTP, and SYBR green dye [ABgene, Epsom, U.K.]) and $500 \mathrm{nM}$ primers (Table 1), using an ABI Prism sequence detection system (Applied Biosystem, Foster City, CA, U.S.A.). PCR conditions were $15 \mathrm{~min}$ at $95^{\circ} \mathrm{C}$, followed by 40 cycles of three steps with $15 \mathrm{~s}$ at $95^{\circ} \mathrm{C}$ (denaturation), $30 \mathrm{~s}$ at $60^{\circ} \mathrm{C}$ (annealing), $45 \mathrm{~s}$ at $72^{\circ} \mathrm{C}$ (extension), and a final step with $15 \mathrm{~s}$ at $95^{\circ} \mathrm{C}, 15 \mathrm{~s}$ at $72^{\circ} \mathrm{C}$, and $15 \mathrm{~s}$ at $95^{\circ} \mathrm{C}$. The activa- tion factor of gene expression was determined with the comparative cycle threshold $(\mathrm{Ct})$ method (Livak and Schmittgen 2001): $2^{-\Delta \Delta \mathrm{Ct}}$; with $\Delta \Delta \mathrm{Ct}=\Delta \mathrm{Ct}$ (treated sample) $-\Delta \mathrm{Ct}$ (control sample) and $\Delta \mathrm{Ct}=\mathrm{Ct}$ (target gene) $-\mathrm{Ct}$ (reference gene). EF1 $\alpha$ was used as the reference gene (Table 1).

\section{Grapevine plants.}

Plant culture conditions. V. vinifera $\mathrm{cv}$. Marselan plants were obtained from herbaceous cuttings placed in individual pots with a mixture of blond peat, sand, and perlite $(4: 1: 1$, $\mathrm{vol} / \mathrm{vol} / \mathrm{vol})$. They were grown until they developed six leaves in a glasshouse at 24 and $18^{\circ} \mathrm{C}$ (day and night, respectively), with a photoperiod of $16 \mathrm{~h}$ and at a relative humidity (RH) of $70 \pm 10 \%$. Plants were watered daily and were fertilized once a week.

Pathogen. P. viticola isolate, obtained from a Burgundy vineyard, was maintained on cv. Marselan herbaceous cuttings as previously described (Trouvelot et al. 2008).

Plant treatment and inoculation. The third leaves from the top of plants were cut, and their petioles were put in distilled water or $5 \mu \mathrm{M}$ DPI for the NADPH oxidase-inhibitor treatment under conditions of $24^{\circ} \mathrm{C}$ day and $18^{\circ} \mathrm{C}$ night, with a photoperiod of $11 \mathrm{~h}$ and at a $\mathrm{RH}$ of $45 \pm 5 \%$. After $24 \mathrm{~h}$, petioles were washed and put in distilled water. Leaves were then treated with water or $30 \mathrm{mM}$ BABA by spraying both upper and lower leaf surfaces until the run-off point for $24 \mathrm{~h}$. BABA $(30 \mathrm{mM})$ was used in planta to lead to induced resistance in our spray-treatment conditions, as previously realized by Cohen and associates (1999) (data not shown). In accordance with Cohen and associates (1999), the application of $30 \mathrm{mM}$ BABA did not cause any phytotoxicity on grapevine leaves. Moreover, $30 \mathrm{mM}$ BABA did not affect zoospore viability in vitro, zoospore germination, or tissue colonization in planta (Supplementary Fig. 3).

Leaves were inoculated by spraying the lower surface with a sporangia suspension of $P$. viticola and were placed in a humid chamber overnight.

Localization of $\mathrm{H}_{2} \mathrm{O}_{2}$ in leaf tissue. Petioles of leaves were put in DAB-HCl $(1 \mathrm{mg} / \mathrm{ml})$ for $6 \mathrm{~h}$. Leaf disks $(1 \mathrm{~cm}$ in diameter $)$ were clarified in a chloral hydrate solution $(2.5 \mathrm{mg} / \mathrm{ml})$ overnight and were washed in phosphate buffer (0.1 M, pH 8.0). After staining with aniline blue, leaf disks were mounted on glass slides (lower surface uppermost), and $\mathrm{H}_{2} \mathrm{O}_{2}$ production was visualized under a microscope (Leica, Wetzlar, Germany) as a brown coloration in plant tissues (Thordal-Christensen et al. 1997).

Observation of mycelium development after aniline blue staining and disease assessment in leaf disks. Clarified leaf disks were stained in $0.05 \%$ aniline blue (in phosphate buffer) overnight and were then mounted on microscope slides in the same solution. Pathogen structure was observed in blue by epifluorescence microscopy under UV $(\lambda \mathrm{ex}=340 \mathrm{~nm}, \lambda \mathrm{em}=380$ $\mathrm{nm}$, stop filter LP $430 \mathrm{~nm}$; Leica).

Disease intensity was assessed by measuring the area covered by sporulation on leaf disks at 7 days postinoculation, as previously performed (Trouvelot et al. 2008).

Table 1. Characteristics of grapevine defense genes

\begin{tabular}{llll}
\hline Gene & \multicolumn{1}{c}{ Forward $^{\mathbf{a}}$} & \multicolumn{1}{c}{ Reverse $^{\mathbf{a}}$} & NCBI gene_ID \\
\hline$E F 1-\alpha$ & GAA CTG GGT GCT TGA TAG GC & AAC CAA AAT ATC CGG AGT AAA AGA & XM_002284888 \\
$R b o h D$ & ACC ATG CTT CAG TCC CTC CAT & AGC GAT CTT CTT GAA GAC TTG TCG CC & XM_002268568 \\
$S T S$ & TAC GCC AAG AGA TTA TCA CT & CTA AAG AGT CCA AAG CAT CT & XM_002263926 \\
$P A L$ & AGT CTC CAT GGA CAA CAC CCG & TGC TCA GCA CTT TCG ACA TGG & XM_002268220 \\
$L O X$ & CTG GGT GGC TTC TGC TCT C & GCA TGA ATC TGC GGC TTA TC & XM_002280615 \\
$P R-2$ & ATG CTG GGT GTC CCA AAC TCG & CAG AAC AAA CTG CGC AAA CCG T & XM_002277133 \\
\hline
\end{tabular}

${ }^{a}$ Primer sequences 5' to $3^{\prime}$ 


\section{ACKNOWLEDGMENTS}

This work was financially supported by the Conseil Régional de Bourgogne, the Bureau Interprofessionnel des Vins de Bourgogne (grant 07 9201 AA O40 S 3627), the Comité National des Interprofessions des Vins d'appelation d'origine, the ANR Génoplante Safegrape project (08GENO-148G), and the ERA NET Plant Genomics PRR-CROP project. C. Dubreuil-Maurizi is supported by a grant from the French Ministère de l'Enseignement Supérieur et de la Recherche. We thank A. Klinguer for excellent technical assistance. We also thank P. Vatsa and S. Bourque for helpful discussion.

\section{LITERATURE CITED}

Ahn, I. P., Kim, S., Lee, Y. H., and Suh, S. C. 2007. Vitamin B1-induced priming is dependent on hydrogen peroxide and the NPR1 gene in Arabidopsis. Plant Physiol. 143:838-848.

Asai, T., Tena, G., Plotnikova, J., Willmann, M. R., Chiu, W. L., GomezGomez, L., Boller, T., Ausubel, F. M., and Sheen, J. 2002. MAP kinase signalling cascade in Arabidopsis innate immunity. Nature 415:977983.

Aziz, A., Heyraud, A., and Lambert, B. 2004. Oligogalacturonide signal transduction, induction of defense-related responses and protection of grapevine against Botrytis cinerea. Planta 218:767-774.

Aziz, A., Gauthier, A., Bezler, A., Poinssot, B., Joubert, J., Pugin, A., Heyraud, A., and Baillieul, F. 2007. Elicitor and resistance-inducing activities of $\beta-1,4$ cellodextrins in grapevine, comparison with $\beta-1,3$ glucans and $\alpha-1,4$ oligogalacturonides. J. Exp. Bot. 58:1463-1472.

Beckers, G. J. M., Jaskiewicz, M., Liu, Y. D., Underwood, W. R., He, S. Y., Zhang, S. Q., and Conrath, U. 2009. Mitogen-activated protein kinases 3 and 6 are required for full priming of stress responses in Arabidopsis thaliana. Plant Cell 21:944-953.

Besson-Bard, A., Courtois, C., Gauthier, A., Dahan, J., Dobrowolska, G., Jeandroz, S., Pugin, A., and Wendehenne, D. 2008. Nitric oxide in plants: Production and cross-talk with $\mathrm{Ca}^{2+}$ signaling. Mol Plant 1:218228

Bindschedler, L. V., Dewdney, J., Blee, K. A., Stone, J. M., Asai, T., Plotnikov, J., Denoux, C., Hayes, T., Gerrish, C., Davies, D. R., Ausubel, F. M., and Bolwell, G. P. 2006. Peroxidase-dependent apoplastic oxidative burst in Arabidopsis required for pathogen resistance. Plant J. 47:851-863.

Boller, T., and Felix, G. 2009. A renaissance of elicitors: Perception of Microbe-Associated Molecular Patterns and danger signals by pattern-recognition receptors. Annu. Rev. Plant Biol. 60:379-406.

Choi, H. W., Kim, Y. J., Lee, S. C., Hong, J. K., and Hwang, B. K. 2007. Hydrogen peroxide generation by the pepper extracellular peroxidase $\mathrm{CaPO}_{2}$ activates local and systemic cell death and defense response to bacterial pathogens. Plant Physiol. 145:890-904.

Cohen, Y., Reuveni, M., and Baider, A. 1999. Local and systemic activity of BABA (DL-3-aminobutyric acid) against Plasmopara viticola in grapevines. Eur. J. Plant Pathol. 105:351-361.

Conrath, U., Beckers, G., Flors, V., Garcia-Agustin, P., Jakab, G., Mauch, F., Newman, M., Pieterse, C., Poinssot, B., Pozo, M., Pugin, A., Schaffrath, U., Ton, J., Wendehenne, D., Zimmerli, L., and MauchMani, B. 2006. Priming: Getting ready for battle. Mol. Plant-Microbe Interact. 19:1062-1071.

Ferrari, S., Galletti, R., Denoux, C., De Lorenzo, G., Ausubel, F. M., and Dewdney, J. 2007. Resistance to Botrytis cinerea induced in Arabidopsis by elicitors is independent of salicylic acid, ethylene, or jasmonate signaling but requires PHYTOALEXIN DEFICIENT3. Plant Physiol. 144:367-379.

Galletti, R., Denoux, C., Gambetta, S., Dewdney, J., Ausubel, F. M., De Lorenzo, G., and Ferrari, S. 2008. The AtrbohD-mediated oxidative burst elicited by oligogalacturonides in Arabidopsis is dispensable for the activation of defense responses effective against Botrytis cinerea. Plant Physiol. 148:1695-1706.

Garcia-Brugger, A., Lamotte, O., Vandelle, E., Bourque, S., Lecourieux, D., Poinssot, B., Wendehenne, D., and Pugin, A. 2006. Early signaling events induced by elicitors of plant defenses. Mol. Plant-Microbe Interact. 19:711-724

Gomez-Gomez, L., and Boller, T. 2002. Flagellin perception: A paradigm for innate immunity. Trends Plant Sci. 7:251-256.

Hamiduzzaman, M., Jakab, G., Barnavon, L., Neuhaus, J., and MauchMani, B. 2005. $\beta$-aminobutyric acid-induced resistance against downy mildew in grapevine acts through the potentiation of callose formation and jasmonic acid signaling. Mol. Plant-Microbe Interact. 18:819-829.

Hammerschmidt, R. 1999. Phytoalexins: What have we learned after 60 years? Annu. Rev. Phytopathol. 37:285-306.

Jaillon, O., Aury, J. M., Noel, B., Policriti, A., Clepet, C., Casagrande, A.,
Choisne, N., Aubourg, S., Vitulo, N., Jubin, C., Vezzi, A., Legeai, F., Hugueney, P., Dasilva, C., Horner, D., Mica, E., Jublot, D., Poulain, J., Bruyere, C., Billault, A., Segurens, B., Gouyvenoux, M., Ugarte, E., Cattonaro, F., Anthouard, V., Vico, V., Del Fabbro, C., Alaux, M., Di Gaspero, G., Dumas, V., Felice, N., Paillard, S., Juman, I., Moroldo, M., Scalabrin, S., Canaguier, A., Le Clainche, I., Malacrida, G., Durand, E., Pesole, G., Laucou, V., Chatelet, P., Merdinoglu, D., Delledonne, M., Pezzotti, M., Lecharny, A., Scarpelli, C., Artiguenave, F., Pe, M. E., Valle, G., Morgante, M., Caboche, M., Adam-Blondon, A.F., Weissenbach, J., Quetier, F., Wincker, P., and French-Italian Public Consortium. 2007. The grapevine genome sequence suggests ancestral hexaploidization in major angiosperm phyla. Nature 449:463-U465.

Jakab, G., Cottier, V., Toquin, V., Rigoli, G., Zimmerli, L., Metraux, J., and Mauch-Mani, B. 2001. $\beta$-aminobutyric acid-induced resistance in plants. Eur. J. Plant Pathol. 107:29-37.

Jakab, G., Ton, J., Flors, V., Zimmerli, L., Metraux, J., and Mauch-Mani, B. 2005. Enhancing Arabidopsis salt and drought stress tolerance by chemical priming for its abscisic acid responses. Plant Physiol. 139:267-274.

Kunz, C., Vandelle, E., Rolland, S., Poinssot, B., Bruel, C., Cimerman, A., Zotti, C., Moreau, E., Vedel, R., Pugin, A., and Boccara, M. 2006. Characterization of a new nonpathogenic mutant of Botrytis cinerea with impaired plant colonization capacity. New Phytol. 170:537-550.

Lebrun-Garcia, A., Ouaked, F., Chiltz, A., and Pugin, A. 1998. Activation of MAPK homologues by elicitors in tobacco cells. Plant J. 15:773-781.

Lherminier, J., Elmayan, T., Fromentin, J., Elaraqui, K. T., Vesa, S., Morel, J., Verrier, J. L., Cailleteau, B., Blein, J. P., and Simon-Plas, F. 2009. NADPH oxidase-mediated reactive oxygen species production: Subcellular localization and reassessment of its role in plant defense. Mol. Plant-Microbe Interact. 22:868-881.

Livak, K. J., and Schmittgen, T. D. 2001. Analysis of relative gene expression data using real-time quantitative PCR and the 2(T)(-Delta Delta C) method. Methods 25:402-408.

Nurnberger, T., Brunner, F., Kemmerling, B., and Piater, L. 2004. Innate immunity in plants and animals: Striking similarities and obvious differences. Immunol. Rev. 198:249-266.

Poinssot, B., Vandelle, E., Bentejac, M., Adrian, M., Levis, C., Brygoo, Y., Garin, J., Sicilia, F., Coutos-Thevenot, P., and Pugin, A. 2003. The endopolygalacturonase 1 from Botrytis cinerea activates grapevine defense reactions unrelated to its enzymatic activity. Mol. Plant-Microbe Interact. 16:553-564

Pozo, M. J., Cordier, C., Dumas-Gaudot, E., Gianinazzi, S., Barea, J. M., and Azcon-Aguilar, C. 2002. Localized versus systemic effect of arbuscular mycorrhizal fungi on defence responses to Phytophthora infection in tomato plants. J. Exp. Bot.53:525-534.

Pugin, A., Frachisse, J. M., Tavernier, E., Bligny, R., Gout, E., Douce, R., and Guern, J. 1997. Early events induced by the elicitor cryptogein in tobacco cells: Involvement of a plasma membrane NADPH oxidase and activation of glycolysis and the pentose phosphate pathway. Plant Cell 9:2077-2091.

Reuveni, M., Zahavi, T., and Cohen, Y. 2001. Controlling downy mildew (Plasmopara viticola) in field-grown grapevine with $\beta$-aminobutyric acid (BABA). Phytoparasitica 29:125-133

Ricci, P., Bonnet, P., Huet, J. C., Sallantin, M., Beauvaiscante, F., Bruneteau, M., Billard, V., Michel, G., and Pernollet, J. C. 1989. Structure and activity of proteins from pathogenic fungi Phytophthora eliciting necrosis and acquired-resistance in tobacco. Eur. J. Biochem. $183: 555-563$

Sagi, M., and Fluhr, R. 2006. Production of reactive oxygen species by plant NADPH oxidases. Plant Physiol. 141:336-340.

Simon-Plas, F., Elmayan, T., and Blein, J. P. 2002. The plasma membrane oxidase NtrbohD is responsible for AOS production in elicited tobacco cells. Plant J. 131:137-147.

Thordal-Christensen, H., Zhang, Z. G., Wei, Y. D., and Collinge, D. B. 1997. Subcellular localization of $\mathrm{H}_{2} \mathrm{O}_{2}$ in plants. $\mathrm{H}_{2} \mathrm{O}_{2}$ accumulation in papillae and hypersensitive response during the barley-powdery mildew interaction. Plant J. 11:1187-1194.

Ton, J., and Mauch-Mani, B. 2004. $\beta$-amino-butyric acid-induced resistance against necrotrophic pathogens is based on ABA-dependent priming for callose. Plant J. 38:119-130.

Ton, J., Jakab, G., Toquin, V., Flors, V., Iavicoli, A., Maeder, M., Metraux, J., and Mauch-Mani, B. 2005. Dissecting the $\beta$-aminobutyric acidinduced priming phenomenon in Arabidopsis. Plant Cell 17:987-999.

Torres, M. A., Dangl, J. L., and Jones, J. D. G. 2002. Arabidopsis gp91(phox) homologues AtrbohD and AtrbohF are required for accumulation of reactive oxygen intermediates in the plant defense response. Proc. Natl. Acad. Sci. U.S.A. 99:517-522.

Torres, M. A., Jones, J. D. G., and Dangl, J. L. 2006. Reactive oxygen species signaling in response to pathogens. Plant Physiol. 141:373-378

Trouvelot, S., Varnier, A., Allegre, M., Mercier, L., Baillieul, F., Arnould, 
C., Gianinazzi-Pearson, V., Klarzynski, O., Joubert, J., Pugin, A., and Daire, X. 2008. A $\beta-1,3$ glucan sulfate induces resistance in grapevine against Plasmopara viticola through priming of defense responses, including HR-like cell death. Mol. Plant-Microbe Interact. 21:232-243.

van Hulten, M., Pelser, M., van Loon, L. C., Pieterse, C. M. J., and Ton, J. 2006. Costs and benefits of priming for defense in Arabidopsis. Proc. Natl. Acad. Sci. U.S.A. 103:5602-5607.

Van Loon, L. C., Bakker, P., and Pieterse, C. M. J. 1998. Systemic resistance induced by rhizosphere bacteria. Annu. Rev. Phytopathol. 36:453483.

Van Loon, L. C., Rep, M., and Pieterse, C. M. J. 2006. Significance of inducible defense-related proteins in infected plants. Annu. Rev. Phytopathol. 44:135-162.

Vandelle, E., Poinssot, B., Wendehenne, D., Bentejac, M., and Pugin, A 2006. Integrated signaling network involving calcium, nitric oxide, and active oxygen species but not mitogen-activated protein kin in BcPG1elicited grapevine defenses. Mol. Plant-Microbe Interact. 19:429-440.

Velasco, R., Zharkikh, A., Troggio, M., Cartwright, D. A., Cestaro, A., Pruss, D., Pindo, M., Fitzgerald, L. M., Vezzulli, S., Reid, J., Malacarne, G., Iliev, D., Coppola, G., Wardell, B., Micheletti, D., Macalma, T., Facci, M., Mitchell, J. T., Perazzolli, M., Eldredge, G., Gatto, P., Oyzerski, R., Moretto, M., Gutin, N., Stefanini, M., Chen, Y., Segala,
C., Davenport, C., Dematte, L., Mraz, A., Battilana, J., Stormo, K., Costa, F., Tao, Q., Si-Ammour, A., Harkins, T., Lackey, A., Perbost, C., Taillon, B., Stella, A., Solovyev, V., Fawcett, J. A., Sterck, L., Vandepoele, K., Grando, S. M., Toppo, S., Moser, C., Lanchbury, J., Bogden, R., Skolnick, M., Sgaramella, V., Bhatnagar, S. K., Fontana, P., Gutin, A., Van de Peer, Y., Salamini, F., and Viola, R. 2007. A high quality draft consensus sequence of the genome of a heterozygous grapevine variety. PLoS ONE 2:e1326. Published online.

Zimmerli, L., Jakab, C., Metraux, J., and Mauch-Mani, B. 2000. Potentiation of pathogen-specific defense mechanisms in Arabidopsis by $\beta$-aminobutyric acid. Proc. Natl. Acad. Sci. U.S.A. 97:12920-12925.

Zimmerli, L., Metraux, J., and Mauch-Mani, B. 2001. $\beta$-aminobutyric acid-induced protection of Arabidopsis against the necrotrophic fungus Botrytis cinerea. Plant Physiol. 126:517-523.

Zimmerli, L., Hou, B., Tsai, C., Jakab, G., Mauch-Mani, B., and Somerville, S. 2008. The xenobiotic $\beta$-aminobutyric acid enhances Arabidopsis thermotolerance. Plant J. 53:144-156.

Zipfel, C., Robatzek, S., Navarro, L., Oakeley, E. J., Jones, J. D. G., Felix, G., and Boller, T. 2004. Bacterial disease resistance in Arabidopsis through flagellin perception. Nature 428:764-767.

Zipfel, C., and Felix, G. 2005. Plants and animals: A different taste for microbes? Curr. Opin. Plant Biol. 8:353-360. 